\title{
Intraductal papillary mucinous neoplasms (IPMN) of the pancreas: clinico-pathologic results
}

\author{
J. A.-Cienfuegos ${ }^{1}$, F. Rotellar ${ }^{1}$, P. Martí-Cruchaga ${ }^{1}$, V. Valentí ${ }^{1}$, G. Zozaya $^{1}$, A. Bueno $^{1}$, N. Pedano ${ }^{1}$, \\ M. D. Lozano ${ }^{2}$, J. J. Sola ${ }^{2}$ and F. Pardo ${ }^{1}$ \\ ${ }^{1}$ Departments of General Surgery and ${ }^{2}$ Pathology. Clínica Universidad de Navarra. Pamplona, Navarra. Spain
}

\begin{abstract}
Background: intraductal papillary mucinous neoplasm (IPMN) shows a series of lesions which evolve from benign lesions -adenoma- to invasive carcinoma.

Aim: to analyze the clinical and pathological results of 15 patients diagnosed of IPMN, and surgically treated according to the guidelines of International Consensus Conference.

Material and methods: a retrospective analysis of 15 patients surgically treated between March 1993 and September 2009, according to the International Consensus recommendation. Demographic, diagnostic tools, surgical report, pathologic database and actuarial survival were analyzed with a follow-up from one and a half month through nine years.

Results: 6 patients underwent pancreaticoduodenectomies, 4 total pancreatectomies, 2 body or central pancreatectomies, 2 partial pancreatectomies (enucleation) and 1 distal pancreatectomy. A morbidity of 46 and $0 \%$ hospital mortality were assessed, with a median length hospital stay of 10 days. In five cases, the IPMN was combined type (both main and branch pancreatic ducts involved) in four main duct-type and branch duct-type in the another six as well. Several atypia (IPMN carcinoma in situ) was observed in 2 patients and invasive carcinoma with negative lymph nodes was identified in 3 patients. A patient without invasive carcinoma died at 66 months of follow-up for pancreas adenocarcinoma. The actuarial survival up to recurrence or death was 105,133 months with a range of follow-up from 1 month and a half until 9 years.

Conclusions: IPMN main duct or mixed type warrants complete resection due to its incidence of invasive carcinoma or precursor lesions of malignancy as well. Due to its multifocal pattern, patients should be followed in long-term surveillance. The management of asymptomatic IPMN type branch less than $3 \mathrm{~cm}$ is controversial.
\end{abstract}

Key words: Intraductal papillary mucinous neoplasm. Prognosis factors. Invasive carcinoma. Survival.

Received: 24-11-09.

Accepted: 09-02-10

Correspondence: Javier A. Cienfuegos. Departamento de Cirugía General. Clínica Universidad de Navarra. Avda. Pío XII, 36. 31008 Pamplona, Navarra. Spain.e-mail: fjacien@unav.es

\section{RESUMEN}

Introducción: la neoplasia papilar mucinosa intraductal (NPMI) del páncreas comprende una serie de lesiones que evolucionan desde lesiones benignas (adenoma) hasta carcinoma ductal invasivo.

Objetivo: analizar los resultados clínicos y patológicos de 15 pacientes diagnosticados de NPMI e intervenidos según las recomendaciones de conferencia de consenso.

Material y métodos: análisis retrospectivo de 15 pacientes con NPMI, intervenidos entre marzo de 1993 y septiembre de 2009; según pautas de conferencias de consenso internacionales. Se recogieron datos demográficos, pruebas diagnósticas, tipo de intervención, histopatología y supervivencia actuarial con un seguimiento entre mes y medio y nueve años.

Resultados: se realizaron 6 duodenopancreatectomías cefálicas, 4 pancreatectomías totales, 2 pancreatectomías centrales, 2 pancreatectomías parciales y una pancreatectomía distal. Se registró una morbilidad del 40\%, sin mortalidad operatoria, con una estancia media de 10 días. En 5 casos la NPMI fue de tipo mixto, en 4 afectaba al conducto pancreático y en los 6 restantes a ramas accesorias. Dos pacientes presentaron carcinoma in situ y 3 carcinoma invasivo con ganglios negativos. Un paciente, sin carcinoma invasivo, falleció a los 66 meses por adenocarcinoma de páncreas. La supervivencia actuarial hasta recidiva o muerte fue de 105,133 meses; con un rango de seguimiento entre mes y medio y 9 años.

Conclusiones: la NPMI tipo ductal y mixto exige la resección completa debido a la elevada incidencia de carcinoma invasivo o de lesiones precursoras de malignidad. Por su carácter multifocal los enfermos deben ser revisados a largo plazo. Existen controversias en las NPMI tipo accesorio asintomáticas y menores de $3 \mathrm{~cm}$.

Palabras clave: Neoplasia papilar mucinosa intraductal. Factores pronósticos. Carcinoma invasivo. Supervivencia.

A.-Cienfuegos J, Rotellar F, Martí Cruchaga P, Valentí V, Zozaya G, Bueno A, Pedano N, Lozano MD, Sola JJ, Pardo F. Intraductal papillary mucinous neoplasms (IPMN) of the pancreas: clinico-pathologic results. Rev Esp Enferm Dig 2010; 102: 314-320. 


\section{INTRODUCTION}

Intraductal papillary mucinous neoplasm (IPMN) of the pancreas encompasses a spectrum of histological and clinical entities which have raised great attention in the last decade (1-6).

The clinical series of IPMN was first described by Ohhashi in 1982 and Sessa introduced the term of IPMN in $1994(7,8)$. The growing histopathological evidence showing that $20-30 \%$ of the IPMN cases are multifocal and that $5-10 \%$ of IPMN disease involve whole pancreatic gland has raised multiple controversies regarding the appropriate surgical treatment and interval follow-up of these patients (1-5).

The most relevant features of IPMN include the pancreatic ducts involvement variants -main duct type, accessory branch type and mixed- and the sequential progression from early lesions as adenoma to in situ carcinoma and invasive carcinoma. There is agreement in considering IPMN as a precursor lesion of pancreatic carcinoma, specially the main duct type lesions (9-13).

Several consensus conferences have been held with the aim of clarifying and establishing the diagnosis requisites and therapeutic recommendations. The aim of this study is to analyze the surgical outcomes of patients diagnosed of IPMN and the concordance of the pathological findings and clinical data with the consensus conference statements (14-16).

\section{PATIENTS AND METHODS}

Between March 1993 and September 2009, 38 patients underwent pancreatic resection for pancreatic cystic tumors. Fifteen of these 38 patients were resected and diagnosed of IPMN and were subject to further analysis.

A retrospective analysis of clinicopathologic data, histopathology, disease free survival and recurrence pattern was performed. The surgical indication was established in multidisciplinary group based on the clinical parameters and imaging techniques: computed tomography (CT), endoscopic ultrasonography (EUS) guided fine-needle aspiration (FNA) and brush cytology, and magnetic resonance cholangiopancreatography (MRCP) according to the mentioned conference guidelines. For the purposes of the study aspirates interpreted as positive for malignancy or positive for mucinous were considered positive for FNA result.

In lesions located in the head, neck or uncinate process, pancreaticoduodenectomy was performed (Krauss-Whipple procedure). Cystic tumors limited to the neck and body were treated with central pancreatectomy and distal pancreatectomy was carried out in tumors located in the tail of the pancreas.

Total pancreatectomy was performed in patients with diffuse involvement of the pancreatic duct. Frozen-section evaluation of the pancreatic transection margin was reported during the operation.
The IPMNs were diagnosed and classified according to the World Health Organization (WHO) nomenclature (17) and with the Osaka's consensus conference held in 2004 (15). Tumors presenting ovarian like stroma were excluded and diagnosed as mucinous adenoma (17).

The IPMN cases were classified in three categories: main-duct type or branch-duct and mixed type as well, depending on the pattern of ductal involvement. The IPMN tumors were classified as non-invasive or invasive according to the criteria published by WHO and later reviewed by Singh and Maitra $(9,17)$.

The surgical margins were evaluated for evidence of gross and microscopic disease according to the 2010 AJCC (Cancer Staging Manual) (18). The positive transection margin was defined as any neoplastic epithelium within ducts. Specific information regarding the status of the retroperitoneal margin, the node involvement, perineural and vascular were reported in the pathological report.

Postoperative mortality was defined as death within the same hospital stay or 30 days of surgery. Pancreatic fistula was defined as output of any measurable volume of fluid with an amylase content greater than three times the serum amylase activity in the percutaneous drainage (19). The site of first recurrence was defined as follows: local indicates the pancreatic bed, regional indicates the peritoneal cavity and distant metastases indicates the liver, bone, lung or others organs of distant metastases. Survival curves were created by using the method of KaplanMeier, with the SPSS program, version 15.0.

\section{RESULTS}

Table I summarizes the clinical characteristics of the entire cohort. The incidence was similar in both genders with and age range between 33 and 79 years (median age 63,2 years), confidence interval (CI): 95\%; 55,95-70,44.

The presenting symptoms were, in general, vague, although five patients presented specific symptoms as jaundice, previous episodes of acute pancreatitis, fever and constitutional syndrome.

Preoperative abdominal CT and EUS-guided FNA were the most common imaging modalities. The FNAcytology was positive for mucinous tumor in 8 of 11 cases (sensitivity $88.8 \%$ ). In two patients the specimen obtained was insufficient.

In 8 patients the tumor involved the head of the pancreas, in three the IPMN presented as diffuse pattern of the main duct. In the remaining four patients, the IPMN was limited to the uncinate process, two in body and the tail of the pancreas as well. Six pancreaticoduodenectomies, four pancreatectomies, two central pancreatectomies, one distal pancreatectomy and two partial pancreatectomies were performed.

There was no operative mortality. Complications were reported in six patients (40\%); four developed collections in the surgical "bed". Three of them required transgastric 
Table I. Summary of clinic-pathological characteristics of 15 IPMN patient surgically treated

\begin{tabular}{|c|c|c|c|c|c|c|c|c|c|c|}
\hline \multirow{2}{*}{$\begin{array}{l}\text { Case } \\
1\end{array}$} & \multicolumn{2}{|c|}{ Age/Sex } & \multirow{2}{*}{$\begin{array}{l}\text { Clinical presentation } \\
\text { Steatorrhea, weight loss }\end{array}$} & \multirow{2}{*}{$\frac{\text { Diagnosis }}{\text { EUS - FNA(t)-CT }}$} & \multicolumn{2}{|c|}{ Location and size } & \multirow{2}{*}{$\begin{array}{c}\text { Surgery } \\
P B\end{array}$} & \multirow{2}{*}{$\begin{array}{l}\text { Pathological findings } \\
\text { Mixed-type. Invasive ca. } \\
\text { Rx margint. Low displasia }\end{array}$} & \multicolumn{2}{|c|}{ Outcomelfollow up } \\
\hline & 79 & M & & & Head & $3.5 \mathrm{~cm}$ & & & Excellent & $9 y$ \\
\hline 2 & 67 & $F$ & Incidental finding & EUS - FNA(t) - ERCP & Head & $2.5 \mathrm{~cm}$ & PD & Mixed-type. Invasive ca. & Excellent & $8 y$ \\
\hline 3 & 72 & $M$ & Astenia/anorexia & EUS - FNA(-) - CT & Head & $2.1 \mathrm{~cm}$ & PD & $\begin{array}{l}\text { Branch-type. Rx margint. } \\
\text { Low displasia }\end{array}$ & Excellent & $6.5 y$ \\
\hline 4 & 77 & $M$ & Abdominal pain, nausea, fever $\left(38^{\circ} \mathrm{C}\right)$ & EUS - FNA(t) - CT & Head & $3 \mathrm{~cm}$ & PD & $\begin{array}{l}\text { Mixed-type. Rx margint. } \\
\text { Low displasia }\end{array}$ & $t$ & $5.5 y$ \\
\hline 5 & 77 & $F$ & Abdominal pain & & Diffuse & $0.4 \mathrm{~cm}$ & $\mathrm{TP}$ & Main-type. PanlN-2 & Excellent & $4 y$ \\
\hline 6 & 73 & $F$ & Incidental finding & EUS - FNA(t) & Diffuse & $0.9 \mathrm{~cm}$ & $\mathrm{TP}$ & Mixed-type. PanIN-1A & Excellent & $4 m$ \\
\hline 7 & 58 & $M$ & Jaundice, weight loss & EUS - FNA(t) & Head & $5.5 \mathrm{~cm}$ & $T P$ & Main-duct type. In situ carcinoma & Excellent & $2.5 y$ \\
\hline 8 & 56 & $F$ & Incidental finding & EUS - FNA(t) & Body - tail & $1 \mathrm{~cm}$ & DP & Branch-type. Pan|N-1A & Excellent & $2 y$ \\
\hline 9 & 33 & $M$ & Relapsing pancreatitis & EUS-CT & Uncinate & $2.5 \mathrm{~cm}$ & Partial P. & Branch-type & Excellent & $2 y$ \\
\hline 13 & 61 & $F$ & Acute pancreatitis & CT - EUS - FNA(t) & Diffuse & $2.5 \mathrm{~cm}$ & TP & Main-duct type. Invasive carcinoma & $\begin{array}{l}\text { Periton. recurrence } \\
\text { Alive }\end{array}$ & $3 y$ \\
\hline 14 & 60 & M & Incidental finding & EUS - FNA(t)-MRCP & Central & $1.7 \mathrm{~cm}$ & $C P$ & Main-duct. Low dysplasia & Excellent & $2 y$ \\
\hline 15 & 76 & $F$ & Anomalies liver function paramet. & EUS - FNA(t) & Head & $1.2 \mathrm{~cm}$ & $P D$ & Branch-type & Excellent & $5.5 y$ \\
\hline
\end{tabular}

EUS: endoscopic sonography; PD: pancreaticoduodenectomy; CT: computed tomography; TP: total pancreatectomy; FNA: fine-needle aspiration; PP: partial pancreatectomy; MRCP: magnetic resonance cholangiopancreatography; CP: central pancreatectomy; ERCP: endoscopic retrograde cholangiopancreatography; DP: distal pancreatectomy.

drainage through EUS. A patient who underwent a partial resection developed a pancreatic fistula at 4 days of discharge, being resolved with percutaneous drainage. Another one developed a delay gastric emptying. The mean hospital stay was 10 days (range 4-22). There was not operative mortality.

Five patients had mixed type of IPMN and three presented the main duct involvement pattern (Fig. 1). In the remaining seven patients the IPMN presented side branches type (Fig. 2). Among the 15 patients, three had

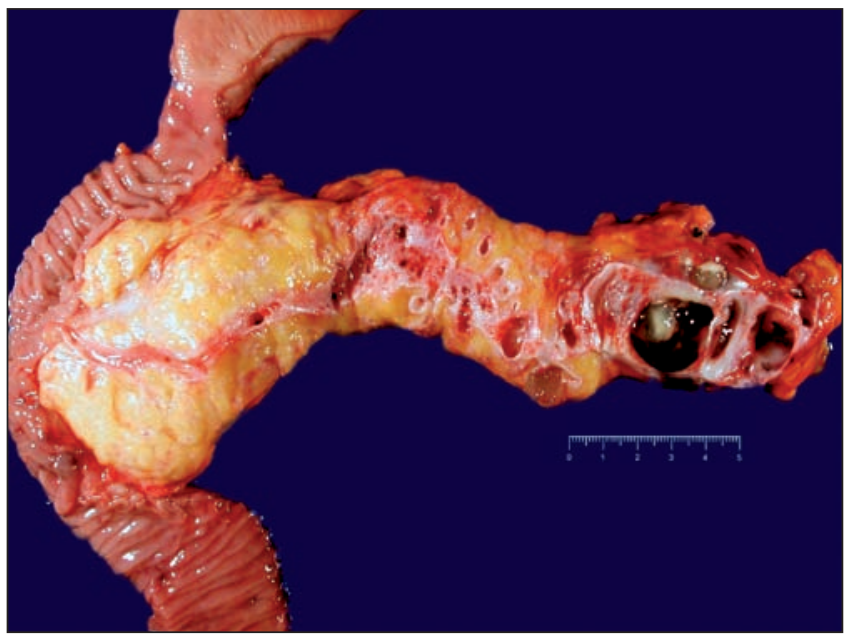

Fig. 1. IPMN specimen of total pancreatectomy showing the main pancreatic duct. A significant dilation from de joint of head and body with cystic dilations containing mucinous in the tail. very low grade dysplasia (adenoma) at the pancreatic transection margin (on frozen-section) analysis. No further resection was performed in these patients.

In three patients pancreatic intraepithelial neoplasia ("PanIN") was assessed. Two of them presented the subtypes PanIN-1A, with flat microscopic lesions (<25 mm) composed of columnar cells and minimal atypia and one case of PanIN-2 with moderate atypia. Two patients presented high-grade dysplasia -in situ carcinoma- (cases 6 and 10) and another three patients (cases 1, 2 y 3) presented an invasive carcinoma with negative nodes in the specimen (Fig. 3). Two of them are alive with no evidence of recurrence at 8 and 9 years of follow-up, meanwhile the remaining patient it is free of disease at three years, having been resected of a peritoneal recurrence at 15 months postsurgery.

One patient (case 4) died at 72 months after diagnosis with multiple node involvement of a pancreatic adenocarcinoma. All patients were followed with a range between 1 month and 9 years, obtaining an actuarial survival of 105,133 months with a confidence index of $95 \%$ (86,264-124,003) and a free-disease survival of 98.355 months (IC: 76,761-119,949). Kaplan-Meier survival curve is depicted in figure 4.

\section{DISCUSSION}

The clinical series of IPMN was first described by Ohhasi in $1982(7,20)$. Sessa posteriously coined the term of IPMN (8). 


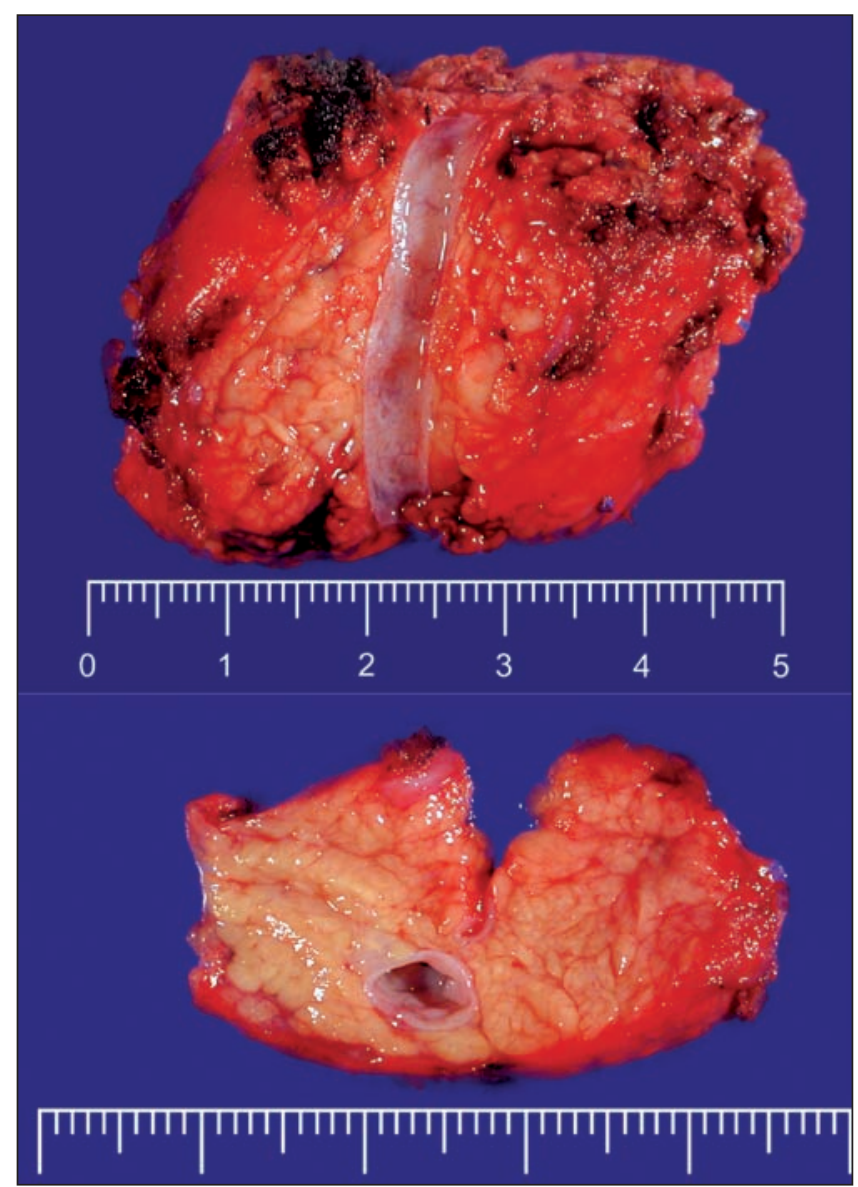

Fig. 2. Gross appearance of central pancreatectomy by IPMN type accessory branch. Pancreatic duct section shows a normal diameter with smooth wall (superior imaging). The pancreas section shows an isolated cystic cavity of $0.9 \mathrm{~cm}$ diameter without communication with the main pancreatic duct.

With occasion of a new classification of the exocrine pancreatic tumor, in 1996 World Health Organization (WHO), defined IPMN as the intraductal papillary growth of mucin-producing columnar epithelia (17). This classification and the revised WHO 2000's classification have disclosured previous misunderstanding and confusing terms $(5,6)$.

A significant number of reports on IPMN have been published in the last decade, accounting between 8 to $20 \%$ pancreatic resections in large-volume centers (22-24). Among its specific characteristics are the different morphological pattern involvement of the duct -side branch duct type and mixed form- and is considered as a premalignant entity, having well documented the sequence from low dysplasia to in situ carcinoma, and invasive carcinoma as well. Several focus of intraepithelial pancreatic neoplasia (PanIN) have been reported in resected specimens and subclassified into different grades of cellular atypia (PanIN-1, PanIN-2, PanIN-3). The PanIN-1 are classified on flat type (PanIN-1A) and papillary type (PanIN-1B).

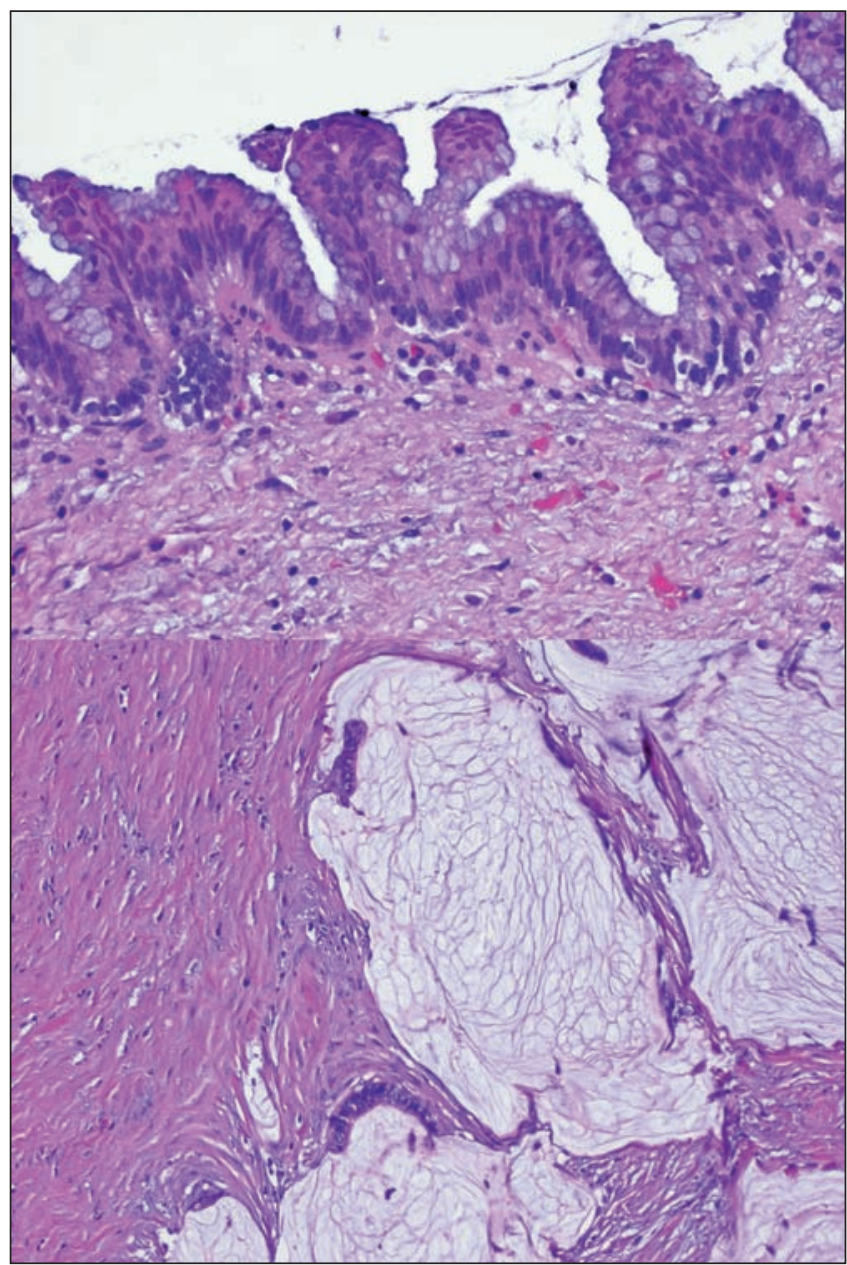

Fig. 3. Microscopic detail of the lesion depicted in figure 1. The main duct is lining by a pseudostratificated epithelium with elongated nuclei, preservation of mucin secretion, mitosis corresponding with highgrade dysplasia (superior H\&E x 400). In the tail of the pancreas an invasive colloid carcinoma with extracellular mucin pools with clusters of malignant cells and stroma component reaction (inferior H\&E x 200) is observed (inferior view H\&E x 200).

Several consensus conferences have been held and guidelines recommendations have been published in order to address the controversies regarding the diagnosis, management and follow-up of IPMN (14-16).

Whereas our case series is limited, represents the second largest in Spanish literature and depicts all the spectrum of IPMN ranging from the benign type -adenomato invasive carcinoma. The demographic profile is similar to other series, presenting in advanced age (70-80 years); perhaps influencing a "nihilist" attitude regarding the surgical treatment in this population.

The most frequent location was in the pancreatic head (10 of 15 cases), and the presenting symptoms are similar with other case series (3,21-25). In our series, four cases with malignancy findings -in situ carcinoma or invasive carcinoma- showed involvement of the main pancreatic duct or a mixed type what is assessed in the majority of authors $(24,26-29)$. 


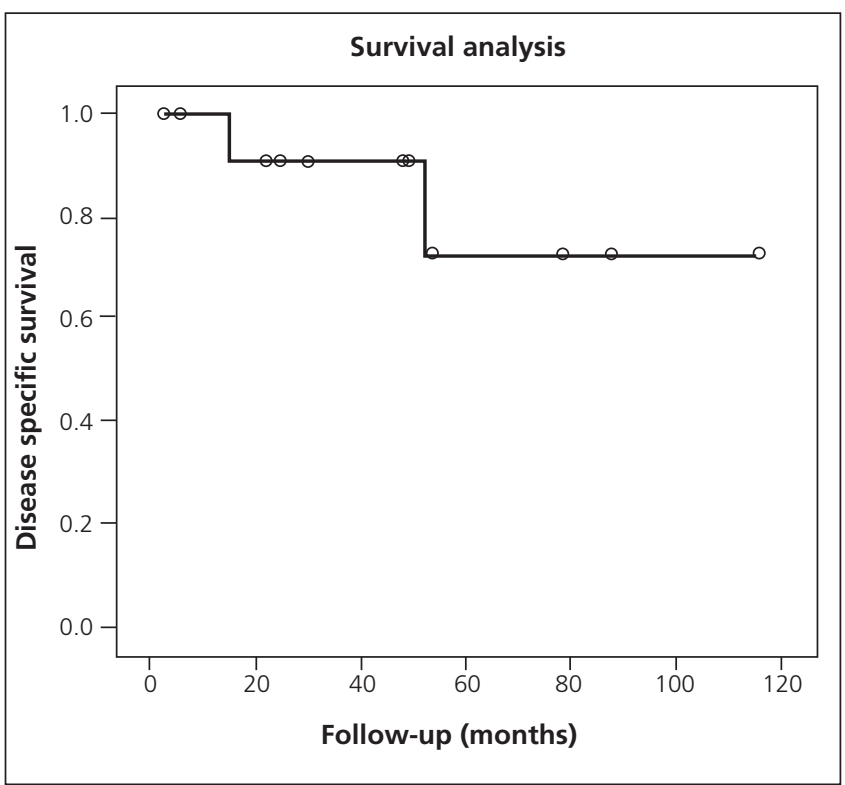

Fig. 4. Kaplan-Meer estimate of overall survival. The median overall survival was 105.133 months.

Supervivencia actuarial de 15 pacientes intervenidos de NPMI hasta recidiva o fallecimiento. La supervivencia media es de 105,133 meses.

In this study, one patient died of loco-regional recurrence of a pancreatic adenocarcinoma at 66 months of follow-up, who had a mixed type of duct involvement in the specimen, the morphologic pattern with more incidence of invasive lesions in large series (24,26-30). The loco-regional relapsing or de novo tumor oscurred at five years and a half after resection, which is the estimated time (5-7 years) to develope the sequence from adenoma to carcinoma in the remanent pancreatic tissue $(9,11,12,24,27)$. Adsay at al, in a very similar series reported two patients with non-invasive IPMN who died of loco-regional recurrence of a pancreatic adenocarcinoma 65 months after surgical resection (21). One of our patients with an invasive carcinoma (case 13) developed localized peritoneal recurrence 15 months after total pan- createctomy. The patient is alive and free of disease after recurrence's resection.

A multifocal IPMN disease has been published in $30 \%$ of the branch-duct type and $10 \%$ of recurrences has been published in non-invasive disease after pancreatectomies with negative margins $(31,32)$. Metachronous or synchronous adenocarcinoma of the pancreas has been reported in $9.2 \%$ of 76 patients with IPMN (33). Three of our patients showed low grade dysplasia in the resection margin. There is agreement that a completion pancreatectomy in not necessary because total pancreatectomy may have severe metabolic consequences $(11,15,16,32,34)$.

The remaining patients are free of disease with a follow-up range between 6 months and 8 years. There was not operative mortality and the $40 \%$ surgical morbidity is according with published range of large experience academic centers $(35,36)$. The median hospital stay was 10.06 days, (range 4-22 days). We have previously mentioned that the invasive carcinoma incidence is more frequent in the main duct type of IPMN (75\%) than in the branch or accessory duct type $(25 \%)(15,24,30,42,43)$. These outcomes justify the prospective study carried out by Salvia in which they performed the follow-up of 89 patients with branch-type IPMN, asymptomatic, size of the lesion less than $3,5 \mathrm{~cm}$ and normal values of CA-19.9. In this study five patients $(6 \%)$ developed an increase in size and underwent resection, without sings of malignization $(44,45)$. Similar results have been published by Tanno et al. through the follow-up of 81 patients during 61 months (46).

Based on this study -evidence grade 3- the guidelines recommend the surveillance and follow-up for the lesions with exclusively involvement of the accessory pancreatic ducts, asymptomatic, less than $3 \mathrm{~cm}$ diameter and absence of nodules inside the lesion $(15,44,47,48)$. The interval between follow-up -high-resolution CT or EUSshould not be longer than 6 months due to higher incidence of metachronous pancreatic adenocarcinoma in the remanent pancreatic tissue $(49,50)$.

Based on previous published experience, we can con-

Table II. Summary of reported outcomes of IPMN(*) surgically treated

\begin{tabular}{|c|c|c|c|c|c|c|c|c|c|c|}
\hline \multirow[t]{2}{*}{ Author } & \multirow[t]{2}{*}{ Year } & \multirow[t]{2}{*}{ \# cases } & \multicolumn{2}{|c|}{ Type IPMN (*) } & \multirow{2}{*}{$\frac{\text { Margin (+) \% }}{\text { Overall }}$} & \multirow{2}{*}{$\begin{array}{l}\text { Follow-up } \\
\bar{X}: \text { months }\end{array}$} & \multicolumn{2}{|c|}{ Loco-regional recurrence } & \multicolumn{2}{|c|}{5 year survival } \\
\hline & & & Non invasive & Invasive & & & Non invasive & Invasive & Non invasive & Invasive \\
\hline Wada K (36) & 2005 & 100 & 75 & 25 & $27 \%$ & 27 & $1.3 \%$ & $42 \%$ & $100 \%$ & $46 \%$ \\
\hline White R (30) & 2007 & 130 & 78 & 60 & $29 \%$ & 40 & \multicolumn{2}{|c|}{$7.7 \%$} & \multicolumn{2}{|c|}{$87 \%$} \\
\hline Nakagohri T (38) & 2007 & 82 & 45 & 37 & - & 28 & \multicolumn{2}{|c|}{$20.7 \%$} & $78 \%$ & $24 \%$ \\
\hline Nara S (39) & 2008 & 104 & 53 & 51 & - & 37.2 & \multicolumn{2}{|c|}{$29.7 \%$} & $100 \%$ & $38 \%$ \\
\hline Nagai K (40) & 2008 & 72 & 42 & 30 & - & 54 & & & $100 \%$ & $57.6 \%$ \\
\hline
\end{tabular}

(*) IPMN: intraductal papillary mucinous neoplasm; $\overline{\mathrm{X}}$ : mean; Margin (+): involvement of pancreatic resection margin. 
clude that IPMN with main duct type pattern and mixed type should be resected with intraoperative confirmation of absence of invasive IPMN at the resection margin. An $80 \%$ survival at five years is estimated for the non-invasive IPMN and $30 \%$ for the cases harboring an invasive carcinoma. Table II shows the recent experience of large series.

\section{REFERENCES}

1. Garcea G, Ong SL, Rajesh A, Neal CP, Pollard CA, Berry DP, et al. Cystic lesions of the pancreas. A diagnostic and management dilemma. Pancreatology 2008; 8: 236-51.

2. Goldsmith JD. Cystic neoplasms of the pancreas. Am J Clin Pathol 2003; 119(1): S3-S16.

3. Basturk O, Coban I, Adsay NV. Pancreatic cysts: pathologic classification, differential diagnosis, and clinical implications. Arch Pathol Lab Med 2009; 133: 423-38.

4. Adsay NV. Cystic lesions of the pancreas. Modern Pathology 2007; 20: 571-93.

5. Seijo Ríos S, Lariño Noia J, Iglesias García J, Lozano León A, Domínguez Muñoz JE. Tumor papilar mucinoso e intraductal: abordaje diagnóstico y terapéutico. Gastroenterol Hepatol 2008; 31: 92-7.

6. Fernández-Esparrach G, Pellisé M, Ginès A. Tumor mucinoso papilar intraductal del páncreas: una entidad más desconocida que infrecuente. Gastroenterol Hepatol 2003; 26: 562-70.

7. Ohhashi K, Murakami Y, Takekoshi T. Four cases of mucous secreting pancreatic cancer (abstr). Prog Diagn Endosc 1982; 20: 348-51.

8. Sessa F, Solcia E, Capella C, Bonato M, Scarpa A, Zamboni G, et al. Intraductal papillary-mucinous tumours represent a distinct group of pancreatic neoplasms: an investigation of tumour cell differentiation and K-ras, p53 and c-erbB-2 abnormalities in 26 patients. Virchows Arch 1994; 425: 357-67.

9. Singh M, Maitra A. Precursor lesions of pancreatic cancer: molecular pathology and clinical implications. Pancreatology 2007; 7(1): 9-19.

10. Hruban RH, Maitra A, Kern SE, Goggins M. Precursors to pancreatic cancer. Gastroenterol Clin North Am 2007; 36: 831-49.

11. Maitra A, Fukushima N, Takaori K, Hruban RH. Precursors to invasive pancreatic cancer. Adv Anat Pathol 2005; 12: 81-91.

12. Maitra A, Hruban RH. Pancreatic cancer. Annu Rev Pathol Mech Dis 2008; 3: 157-88.

13. Serikawa M, Sasaki T, Fujimoto Y, Kuwahara K, Chayama K. Management of intraductal papillary-mucinous neoplasm of the pancreas: treatment strategy based on morphologic classification. J Clin Gastroenterol 2006; 40: 856-62.

14. Furukawa T, Klöppel G, Volkan Adsay N, Albores-Saavedra J, Fukushima N, Horii A, et al. Classification of types of intraductal papillary-mucinous neoplasm of the pancreas: a consensus study. Virchows Arch 2005; 447: 794-9.

15. Tanaka M, Chari S, Adsay V, Fernandez-del Castillo C, Falconi M, Shimizu M, et al.; International Association of Pancreatology. International consensus guidelines for management of intraductal papillary mucinous neoplasms and mucinous cystic neoplasms of the pancreas. Pancreatology 2006; 6: 17-32.

16. Hruban RH, Takaori K, Klimstra DS, Adsay NV, Albores-Saavedra $\mathrm{J}$, Biankin AV, et al. An illustrated consensus on the classification of pancreatic intraepithelial neoplasia and intraductal papillary mucinous neoplasms. Am J Surg Pathol 2004; 28: 977-87.

17. Kloppel G, Solcia E, Longnecker DS, Capella C, Sobin LH. Histological typing of tumours of the exocrine pancreas. In: World Health Organization International Classification of Tumours. $2^{\text {nd }}$ ed. Berlin: Springer; 1996. p. 11-20.

18. Edge SB, Byrd DR, Compton EC, Fritz AG, Greene FL, Trotti A, editors. Exocrine and endocrine pancreas. En: AJCC. Cancer staging manual. $7^{\text {th }}$ ed. New York: Springer-Verlag; 2010. p. 241-9.

19. Bassi C, Dervenis C, Buturrini G, Fingerhut A, Yeo C, Izbicki J, et al.; International Study Group on Pancreatic Fistula Definition. Postoperative pancreatic fistula: as international study group (ISGPF) definition. Surgery 2005: 138: 8-13.
20. Ohhashi K, Takagi K. ERCP and imaging diagnosis of pancreatic cancer (Abstr). Endoscopy 1980; 77: 1493-5.

21. Adsay NV, Conlon KC, Zee SY, Brennan MF, Klimstra DS. Intraductal papillary-mucinous neoplasms of the pancreas: an analysis of in situ and invasive carcinomas in 28 patients. Cancer 2002; 94: 62-77.

22. Raut CP, Cleary KR, Staerkel GA, Abbruzzesse JL, Wolff RA, Lee $\mathrm{JH}$, et al. Intraductal papillary mucinous neoplasms of the pancreas: effect of invasion and pancreatic margin status on recurrence and survival. Ann Surg Oncol 2006; 13: 582-94.

23. Ubiña Aznar E, Rivera Irigoin R, Méndez Sánchez I, Fernández Moreno N, García Fernández G, Sánchez Cantos A. Endoscopic signs of mucinous tumor of the pancreas. Rev Esp Enferm Dig 2007; 7: 413-4

24. Sohn TA, Yeo CJ, Cameron JL, Hruban RH, Fukushima N, Campbell KA, et al. Intraductal papillary mucinous neoplasms of the pancreas: an updated experience. Ann Surg 2004; 239: 788-97.

25. Marín Serrano E, Macías Rodríguez MA, Rendón Unceta P, Pérez Requena J, Guillén Mariscal P, Martín Herrera L. Pancreatic intraductal papillary mucinous tumor. Rev Esp Enferm Dig 2005; 11: 836-7.

26. Schnelldorfer T, Sarr MG, Nagorney DM, Zhang L, Smyrk TC, Qin $\mathrm{R}$, et al. Experience with 208 resections for intraductal papillary mucinous neoplasm of the pancreas. Arch Surg 2008; 143: 639-46.

27. Salvia R, Fernández-del Castillo C, Bassi C, Thayer SP, Falconi M, Mantovani W, et al. Main-duct intraductal papillary mucinous neoplasms of the pancreas: clinical predictors of malignancy and longterm survival following resection. Ann Surg 2004; 239: 678-85.

28. Yang AD, Melstrom LG, Bentrem DJ. Outcomes after pancreatectomy for intraductal papillary mucinous neoplasms of the pancreas: an institutional experience. Surgery 2007; 142: 529-34.

29. D'Angelica M, Brennan MF, Suriawinata AA, Klimstra D, Conlon KC. Intraductal papillary mucinous neoplasms of the pancreas: an analysis of clinicopathologic features and outcome. Ann Surg 2004; 239: 400-8.

30. Rodriguez JR, Salvia R, Crippa S, Warshaw AL, Bassi C, Falconi M, et al. Branch-duct intraductal papillary mucinous neoplasms: observations in 145 patients who underwent resection. Gastroenterology 2007; 133: 72-9.

31. White R, D'Angelica M, Katabi N, Tang L, Klimstra D, Fong Y, et al. Fate of the remnant pancreas after resection of noninvasive intraductal papillary mucinous neoplasm. J Am Coll Surg 2007; 204: $987-$ 93.

32. Chari ST, Yadav D, Smyrk TC, DiMagno EP, Miller LJ, Raimondo $\mathrm{M}$, et al. Study of recurrence after surgical resection of intraductal papillary mucinous neoplasm of the pancreas. Gastroenterology 2002; 23: 1500-7.

33. Yamaguchi K, Ohuchida J, Ohtsuka T, Nakano K, Tanaka M. Intraductal papillary-mucinous tumor of the pancreas concomitant with ductal carcinoma of the pancreas. Pancreatology 2002; 2: 484-90.

34. Andea A, Sarkar F, Adsay VN. Clinicopathological correlates of pancreatic intraepithelial neoplasia: a comparative analysis of 82 cases with and 152 cases without pancreatic ductal adenocarcinoma. Mod Pathol 2003; 16: 996-1006.

35. Joseph B, Morton JM, Hernandez-Boussard T, Rubinfeld I, Faraj C, Velanovich V. Relationship between hospital volume, system clinical resources, and mortality in pancreatic resection. J Am Coll Surg 2009; 208: 520-7.

36. van Heek NT, Kuhlmann KF, Scholten RJ, de Castro SM, Busch OR, van Gulik TM, et al. Hospital volume and mortality after pancreatic resection: a systematic review and an evaluation of intervention in the Netherlands. Ann Surg 2005; 242: 781-8.

37. Wada K, Kozarek RA, Traverso W. Outcomes following resection of invasive and noninvasive intraductal papillary mucinous neoplasms of the pancreas. Am J Surg 2005; 189: 632-7.

38. Raut CP, Cleary KR, Staerkel GA, Abbruzzesse JL, Wolff RA, Lee $\mathrm{JH}$, et al. Intraductal papillary mucinous neoplasms of the pancreas: effect of invasion and pancreatic margin status on recurrence and survival. Ann Surg Oncol 2006; 13: 582-94.

39. Nakagohri T, Kinoshita T, Konishi M, Takahashi S, Gotohda N. Surgical outcome of intraductal papillary mucinous neoplasms of the pancreas. Ann Surg Oncol 2007; 14: 3174-80.

40. Nara S, Shimada K, Kosuge T, Kanai Y, Hiraoka N. Minimally inva- 
sive intraductal papillary-mucinous carcinoma of the pancreas: clinicopathologic study of 104 intraductal papillary-mucinous neoplasms. Am J Surg Pathol 2008; 32: 243-55.

41. Nagai K, Doi R, Kida A, Kami K, Kawaguchi Y, Ito T, et al. Intraductal papillary mucinous neoplasms of the pancreas: clinicopathologic characteristics and long-term follow-up after resection. World $\mathbf{J}$ Surg 2008; 32: 271-8.

42. Terris B, Ponsot P, Paye F, Hammel P, Sauvanet A, Molas G, et al. Intraductal papillary mucinous tumors of the pancreas confined to secondary ducts show less aggressive pathologic features as compared with those involving the main pancreatic duct. Am J Surg Pathol 2000; 24: 1372-7.

43. Kobari M, Egawa S, Shibuya K, Shimamura H, Sunamura M, Takeda $\mathrm{K}$, et al. Intraductal papillary mucinous tumors of the pancreas comprise 2 clinical subtypes: differences in clinical characteristics and surgical management. Arch Surg 1999; 134: 1131-6.

44. Salvia R, Crippa S, Falconi M, Bassi C, Guarise A, Scarpa A, et al. Branch-duct intraductal papillary mucinous neoplasms of the pancreas: to operate or not to operate? Gut 2007; 56: 1086-90.

45. Ghaneh P, Neoptolemos J. A new approach to managing intraductal papillary mucinous pancreatic neoplasms. Gut 2007; 56: 1041-4.

46. Tanno S, Nakano Y, Nishikawa T, Nakamura K, Sasajima J, Minoguchi M, et al. Natural history of branch duct intraductal papillary-mucinous neoplasms of the pancreas without mural nodules: long-term follow-up results. Gut 2008; 57: 339-43.

47. Bassi C, Sarr MG, Lillemoe KD, Reber HA. Natural history of intraductal papillary mucinous neoplasms (IPMN): current evidence and implications for management. J Gastrointest Surg 2008; 12 : 645-50.

48. Woo SM, Ryu JK, Lee SH, Yoon WJ, Kim YT, Yoon YB. Branch duct intraductal papillary mucinous neoplasms in a retrospective series of 190 patients. Br J Surg 2009; 96: 405-11.

49. Tanno S, Nakano Y, Koizumi K, Sugiyama Y, Nakamura K, Sasajima J, et al. Pancreatic ductal adenocarcinomas in long-term followup patients with branch duct papillary mucinous neoplasms. Pancreas 2010; 39: 36-40.

50. Belyaev O, Seeling MH, Muller CA, Tannapfel A, Schmidt WE, Uhl W. Intraductal papillary mucinous neoplasms of the pancreas. J Clin Gastroenterol 2008; 42: 284-94. 
